the large arteries as always synonymous with accelerated circulation.

The heart, no doubt, is the principal agent in the circulation in the arteries, but arrived at the capillaries its supremacy is usurped by the vis a fronte. How, then, can that whieh retards the interchanges- between the blood in the capillaries and the tissues about them be regarded as the most powerful stimulant to the circulation?

In cholera it appears desirable not to retard, but to favour oxidation; and as the caustic alkalies promote that change, I gave, during the last epidemic of cholera, the solution of anmonia in hot water to three cholera patients who came under my care, whilst at intervals they inhaled oxygen from Dr. Beigel's inhaler, with apparent benefit. The three cases recovered without any alcohol. As a disinfectant, a dilute solution of permanganate of potash was thrown up the bowel two or three times during the day, as hot as the patients could bear it.

Probably in fever, and diseases of peroxidation, the antiseptic virtues of carbolic acid are indicated, and in cholera collapse the disinfecting properties of the permanganates. I am, Sir, your obedient servant,

Sunderland, Oct. 22, 1867

$$
\text { MoRdeY Dodgras, M.R.C.S. Eng. }
$$

\section{COUNTRY WORKHOUSE REFORM.}

\section{To the Editor of THE LANCRT.}

Sir,-_I am pleased to find that your Workhouse Infirmary Commissioners have so vigorously commenced their inspection of the provincial union infirmaries. I have long known from constant communication with my country brethren, and also from other sources, that you would discover in them abuses and irregularities which would throw into the shade all that your staff has so ably exposed in London.

But I am afraid lest any provincial Poor-law brethren should fancy that your Commission will be calculated, if helped in any way by them, to embroil them with the guardians, and, taking counsel of their fears, may cast in their lot with them. I beg, if I may be permitted as an old and, I trust, earnest Poor-law medical reformer, to urge them to aid and assist you in every way. The agitation which terminated in the Metropolitan Poor-law Act was the immediate result of your Commission's labours; and if in our day and generation. the condition of the sick poor on the one hand, and that of their medical atttendants on the other, is to be materially altered for the better in country districts, it will only be as the result of the exposures of the wrong-doings of the existing system which your Commission can, if fearlessly worked and assisted by the medical officers, bring to light.

Isolated as my country brethren are, there is no hope of much success from any agitation initiated by them; by availing themselves, however, of the aid you offer them, a successful result may soon be obtained now that public opinion has pronounced itself so strongly in our favour.

$$
\text { I am, Sir, yours obediently, }
$$
Jos. Rogers,

oct. 1867. President of the London and Provineial Poor-law Medical Officers' Association.

\section{MEDICAL EDUCATION AT OXFORD AND CAMBRIDGE.}

\section{To the Editor of THE LaNcer.}

Sir, - Your leading article of last week on this subject will, I am sure, be read with great satisfaction, for all are agreed that the universities ought to exercise a greater influence than they do upon our profession, and most persons are of opinion that religious restrictions ought not to interfere. I think, however, that many who read your article will be led to infer that those restrictions are greater than is really the case. As far as the University is concerned, I speak particularly of Cambridge, only one remnant of such restriction now remains. A person of any religious persuasion, or, indeed, without anyfor he is not questioned upon the subject,--may matriculate, keep terms, proceed to and take any degree (the theological degrees, of course, excepted), and enjoy all privileges which the University can affurd. The only point is, that he does not become a member of the State, or ruling body of the
University, unless he is a member of the Church of England. The almost successful efforts to sweep away this restriction in the last session of Parliament you will remember. In the colleges also there are representatives of various creeds, and they may all compete for and hold the scholarships; but the fellowships are, by Act of Parliament, reserved for members of the Church of England. The ill effect of this has been felt in several of the colleges, because it has prevented them from retaining some of their ablest men. Not long ago a nonconformist undergraduate of Trinity College was senior wrangler, but the College lost the benefit of lis services as a teacher because he could not be made a Fellow. Had it been in the power of the College they would, I believe, gladly have done so; indeed, a petition to have the restriction removed, and the power given to elect nonconformists Fellows of the colleges, was unanimousily signed.

All, therefore, in the way of education, degrees, exhibitions, and scholarships that the university and the colleges can give are open to members of all religious denominations. The membership of the Senate and the fellowships of colleges remain to be thrown open.

Oct. 19th, 1867. I am, Sir, yours obediently,

M.D. Cantab.

\section{To the Editor of The LANCET.}

SIR,-I was much pleased by the perusal of your excellent article on the older universities, and especially by your remarks on the Cambridge Medical School. There is one point upon which it would be productive of great advantage if you would use your influence with the authorities. There are no lectures on "descriptive and surgical anatomy," such as are required by the College of Surgeons.

I believe the want only requires to be laid before the "Board of Medical Studies" in order that it may be supplied, for I am sure all are anxious that nothing should be wanting to make Cambridge a most noted school of medicine and science.

King's College, Cambridge.

$$
\text { I am, Sir, yours truly, }
$$
AN UNDERGRADUATE.

\section{THE INQUEST AT REDCAR. \\ To the Editor of THe LANCET.}

SIR,-An extract from your number of the 5th having appeared in the Middlesborough Gazette of this week, relative to the above case, I feel called upon, as a duty I owe to the profession generally, after your comments, to afford my explanation and reason for acting as I have done. Believing the principle advocated by you to be "audi alteram partem," therefore I conclude you will accord that justice to me, as a member of the profession, by the insertion of this letter. I must, in the first place, draw your attention to some inaccurate remarks, of a most important nature, in your quotations upon the case. First, "That another attempt was made by Dr. Bennett to enter the bladder," but again unsuecessfully, \&c. Secondly, "That the man Errington died at ten o'clock on Friday morning." Both these statements are incorrect; as, according to the evidence of the deceased, and the woman in attendance upon him, Dr. Bennett did not make a second attempt to pass the catheter; and the man died about eleven o'clock on the evening of Friday.

When I was called upon professionally to see Frrington, on the afternoon of the 18th, I found him in a state of collapse, almost pulseless, complaining of extreme pain over the lower portion of the abdomen. Upon examination, I found the bladder enormously distended, marks of ecchymosis over its site, the penis much tumefied. The poor man's history was that he had not passed any urine since the Monday evening that Dr. Bennett had put him to great pain by using force to pass the instrument for over an hour, not succeeding.

Seeing the nature and urgency of the case I returned home for my catheters, and upon my return was able to pass without difficulty No. 4, relieving him of three or four pints of urine of a dark colour, and strong odour. On the afternoon of Thursday, and the morning of Friday, I again succeeded with more or less difficulty, owing to the more general tumefaction of the penis, and on the last occasion leaving the catheter there until he died. My treatment beyond this was ammonia, beeftea, and brandy; notwithstanding which the shock to the nervous system was so great that he died from its effect. 